\title{
Щукин М.А. \\ Стороны брачного договора в российском и зарубежном праве
}

Кубанский государственный аграрный университет им. И. Т. Трубилина

(Россия, Краснодар)

doi: 10.18411/trnio-01-2022-205

\section{Аннотация}

В данной статье рассмотрены стороны брачного договора не только в российском праве, но и в и зарубежном. Брачный договор относится к личным сделкам и может быть заключен только при непосредственном присутствии супругов или лиц, заключающих брак, без права заключения таких договоров через представителей. Эту позицию поддерживает большинство авторов, но также и нотариальная практика сопровождения этого «супружеского договора». Данная тема весьма актуальная, так как до сегодняшнего времени ей не уделялось достаточного внимания. Важен не только теоретический, но и практический аспект данного вопроса. Исследуется научная литература по заданной проблеме, а также практический отечественный опыт.

Ключевые слова: семья, брачный договор, зарубежное право, российское право, юриспруденция, семейное право.

\section{Abstract}

This article examines the parties to a marriage contract not only in Russian law, but also in foreign law. A marriage contract refers to personal transactions and can be concluded only with the direct presence of spouses or persons entering into marriage, without the right to conclude such contracts through representatives. This position is supported by most of the authors, but also by the notarial practice of accompanying this "marriage contract". This topic is very relevant, since until now it has not received sufficient attention. Not only the theoretical, but also the practical aspect of this issue is important. The scientific literature on the given problem, as well as practical domestic experience, is being studied.

Keywords: family, marriage contract, foreign law, Russian law, jurisprudence, family law.

Актуальность темы научной работы состоит в том, что с использованием брачного договора молодые супруги получают образование, позволяющее определить имущество и имущественные отношения в будущей семьи. С развитием рыночных отношений в Российской Федерации каждый супруг вправе распоряжаться собственным имуществом по своему решению, независимо от желания другого супруга, правовой механизм данного права закреплен в институте брачного договора [1], поэтому рассмотрим стороны брачного договора в Российском и Зарубежном праве. Опыт зарубежных стран и складывающая российская практика свидетельствует о том, что, как правило, заключение брачного договора предшествует вступлению в брак.

Согласно семейному законодательству брачный договор могут заключать брачующиеся либо супруги, это положение закреплено в статье 40 "Семейный кодекс Российской Федерации" от 29.12.1995 N 223-Ф3 [2].

Что касается второй категории людей, то ни в теории, ни на практике особых проблем и расхождений нет, так как супруги на протяжении всей семейной жизни могут устанавливать схожие правовые имущественные отношения.

В то же время следует отметить, что понятие супруга в Российской Федерации может существенно отличаться от такового в некоторых зарубежных странах, где однополые пары могут официально быть супругами (Исландия, Бельгия, Швеция, Дания и др.). Практика регистрации однополых браков гражданами Российской Федерации в других государствах, где такие отношения разрешены законом. 
Брачный договор относится к личным сделкам и может быть заключен только при непосредственном присутствии супругов или лиц, заключающих брак, без права заключения таких договоров через представителей. Эту позицию поддерживает большинство авторов, но также и нотариальная практика сопровождения этого «супружеского договора» [3].

Однако есть и другое мнение, сторонники которого рассматривают брачный договор как гражданско-правовое дело и заключение такого договора через представителя по официально оформленной доверенности, а также через законного представителя. Заключение брачного контракта по доверенности нежелательно, но возможно в исключительных случаях [4].

Зарубежное законодательство по-разному подходит к этому вопросу. В принципе, личное присутствие супруга также обязательно. Однако во Франции и Германии брачный договор может быть заключен представителем со специальным доверительным управляющим, который содержит условия договора.

Поскольку заключение брачного контракта тесно связано с браком или статусом супружеских отношений, которые носят сугубо личный характер, мы считаем, что заключение таких соглашений в отсутствие одного из супругов (супруга) не является допустимым и также противоречит концепции построения правовых семейных отношений, закрепленной в положениях семейного права [5].

Противоречивы также возраст, с которого возможен брак, и порядок заключения брачного контракта. Даже в пределах России возраст может быть изменен законодательством отдельных субъектов Федерации. Таким образом, определение профессионального состава лиц, которые могут заключать брачный договор, намного шире, чем формулировка статьи 40 СК РФ. Здесь требуется более подробное толкование на основе ряда норм семейного и гражданского права.

Согласно семейному законодательству России супругами могут быть только дееспособные граждане (ст. 14 СК РФ) разного пола (ст. 12 СК РФ), достигшие брачного возраста (ст. 13 СК РФ) - 18 лет (в отдельных, установленных законодательством случаях он может быть снижен), которые не состоят в близких родственных связях или иных зарегистрированных семейных отношениях (ст. 14 СК РФ).

Вместе с этим, существуют некоторые исключения. Если гражданин не достиг брачного возраста, но получил разрешение органа местного самоуправления на регистрацию брака, то он может заключить брачный договор до момента официального оформления отношений с письменного согласия родителей или попечителей (ст. 26 ГК РФ). После заключения брака несовершеннолетний супруг становится дееспособным в полной мере (ст. 21 ГК РФ), а значит, может оформлять и подписывать подобный контракт самостоятельно.

Ст. 40 СК РФ указывает, что брачный договор могут заключить лица, вступающие в брак. Однако ни сам СК РФ, ни какие-либо иные нормативные правовые акты не дают никаких указаний относительно того, кого считать лицами, вступающими в брак. Считаем, что лицами, вступающими в брак, являются лица, намеревающиеся заключить брак в будущем, и независимо от факта подачи этими лицами заявления о регистрации брака в органы ЗАГСа.

Нотариус при обращении к нему лиц, еще не состоящих в браке между собой, не только вправе, но и обязан удостоверить брачный договор между такими лицами, конечно, если такой договор будет полностью соответствовать действующему законодательству. Нотариус в данном случае не вправе требовать от лиц предоставления различного рода справок из органов ЗАГСа, подтверждающих факт подачи этими лицами заявления о регистрации брака. Однако нотариальное удостоверение подобного брачного договора будет обладать определенной спецификой. И эта специфика будет выражаться в том, что нотариус в тексте брачного договора должен будет сделать специальную оговорку, что договор вступит в силу только с момента государственной регистрации брака между сторонами брачного договора. 
В заключении выделим, еще одно обстоятельство, которое имеет как практическое, так и теоретическое значение при заключении и признании брачного договора действительным - это официальность брака. Любой семейный союз должен быть соответствующе оформлен. В России процедура регистрации брака осуществляется в органах ЗАГС (ст. 1, 10 СК РФ), за ее пределами в дипломатических представительствах или в консульских учреждениях РФ (ст. 157 СК РФ) предоставлены соответствующие полномочия на государственную регистрацию актов гражданского состояния. Религиозная или иная форма оформления семейных отношений (обычай, договор и т.д.) в России не влечет за собой правовых последствий, в том числе и имущественных.

\section{$* * *$}

1. Гражданское право: учебник для студентов вузов, обучающихся по специальности Юриспруденция / Н. Д. Эриашвили, П. В. Алексий, И. В. Петров [и др.]; Под редакцией: М.М. Рассолова, О.Ю. Ильиной, А.Н. Кузбагарова. - Издание 4-е, переработанное и дополненное. - Москва: Общество с ограниченной ответственностью "Издательство "Юнити-Дана", 2012. - 911 с.

2. Семейный кодекс Российской Федерации от 29.12.1995 N 223-Ф3 (актуальная редакция) // С3 РФ, от 1 января 1996 г. N 1 ст. 16. Доступ из справ. -правовой системы «Консультант Плюс».

3. Корнеева, И. Л. Семейное право: учебник и практикум для СПО / И. Л. Корнеева. - М.: Юрайт, 2016. - 361 с.

4. Крашенинников, П. В. Семейное право учебник / П. В. Крашенинников. - М.: Статут, 2016. -270 с.

5. Сабитова Э.Н. Брачный договор как способ защиты прав супругов в нотариальной деятельности // Нотариус. 2015. № 6. С. 18. 